\title{
Balancing Healthcare and Economy Amidst the COVID-19 Pandemic: An Indian Experience
}

This article was published in the following Dove Press journal:

Risk Management and Healthcare Policy

\author{
Ruby Dhar ${ }^{1, *}$ \\ Babban Jee ${ }^{2, *}$ \\ Subhradip Karmakar' \\ 'Department of Biochemistry, All India \\ Institute of Medical Sciences, New Delhi, \\ India; ${ }^{2}$ Department of Health Research, \\ Ministry of Health and Family Welfare, \\ Government of India, New Delhi, India \\ *These authors contributed equally to \\ this work
}

Correspondence: Subhradip Karmakar All India Institute of Medical Sciences, New Delhi, India

Email subhradip.k@aiims.edu

\begin{abstract}
With its 1.3 billion population and faced with the COVID-19 pandemic, India is at the junction of two crucial decisions, balancing healthcare and the economy. To prevent the community spread of the virus, the Indian Government imposed a nationwide lockdown. Though initially successful to some extent in containing the disease spread, the extended lockdown eventually leads to a spiraling out effect resulting in the slowdown of the economy, which, in turn, lead to widespread consequences affecting the lives of millions of people, mostly those at the base of the social pyramid. We investigated the implications of few government policies taken during this pandemic and their impact on society, thereby suggesting short-term crisis management with long-term solutions. Here, we present a comprehensive account of Indian policy in dealing with the COVID-19 crisis, balancing both economic and public health. We also explored a future contingency plan for risk mitigation along with few recommendations. This viewpoint will be useful for effective healthcare management and the economy in Asia's populous nation in the COVID-19 and prepare for a future crisis of this nature.
\end{abstract}

Keywords: COVID-19, India, economic crisis, healthcare, vaccination, management

\section{Introduction}

COVID-19 caused due to the SARS-CoV-2 virus is a rapidly evolving pandemic affecting 213 countries, with over 80 million cases and 1.8 million deaths worldwide. In India alone, COVID-19 accounts 10,324,631 cases and 149,471 fatalities. ${ }^{1}$ The rising number of cases and mortality seems to stretch the operational capacity of financial institutions and healthcare systems of even the developed nations at the brink of collapse. Emerging economies like India are at a colossal risk for financial bankruptcy, recession, and chaos. With the implementation of an extensive countrywide lockdown (from March 25th, 2020 till March 31st, 2020) in the world's second-most populous nation with $\$ 2.87$ trillion economy ${ }^{2}$ to flatten the pandemic curve, the economically impoverished sections of India are on the verge of desperation and severe crisis. Though the government-sponsored aid programs seem to offer some buffer, it is still grossly insufficient to deal with the massive fallout. With no definite curative medicine in place, COVID-19 has unleashed a humanitarian crisis of disproportionate magnitude, leaving minimal maneuver options. Even though the early response to this crisis was not-substantial, we saw significant development later indicating a radical shift in healthcare and fiscal policy to counter the situation. Today, India boasts of one of the world's lowest COVID-related mortality and is all geared up to lunch the world's largest 
vaccination program against COVID-19. In this scenario, we experienced both a short-term exit strategy and a longterm contingency plan that may need to be chalked out to handle the present situation, prioritizing healthcare and the economy following a two-pronged approach to overcome the present economic slump.

\section{Therapeutic and Preventive Options for COVID- 19}

India's bet on cheap and affordable medicine for its large population fueled the repurposing of several drugs, including the antimalarial drug hydroxychloroquine (HCQ), for COVID-19 prophylaxis. $^{3}$ However, it was soon realized that HCQ could not serve as a solution to this pandemic. ${ }^{4,5}$ Further, with HCQ not under recommendation for COVID-19 prophylaxis by the World Health Organization (WHO) and European Union (E.U.) due to its adverse effect on health and cardiovascular risk and no significant beneficial effect on COVID-19 severity $^{6-8}$ the hope is on a few candidates like Gilead's Remdesiver and similar, which are currently being recommended in India with some beneficial outcome. National Institute of Allergy and Infectious Diseases (NIAID), USA sponsored Adaptive COVID-19 Treatment Trial (ACTT) trial showed Remdesivir with a shorter recovery time in adults with COVID-19 as compared to the placebo. ${ }^{9}$ Furthermore, a recently completed ACTT-2 trial conducted to see the efficacy of anti-inflammatory Baricitinib to Remdesivir in treating the COVID-19 patients showed that Baricitinib plus Remdesivir were superior to Remdesivir alone in treating the severe COVID-19 patients. $^{10}$ The interim findings of one of the most extensive international clinical trials launched by WHO over 30 countries, including India with 11,330 COVID-19 patients, referred to as the WHO Solidarity Trial, which was conducted to explore an effective treatment option for COVID-19, demonstrated that all four treatments (Remdesivir, hydroxychloroquine, lopinavir, and interferon- $\beta 1 \mathrm{a}$ ) had little or no benefits in hospitalized COVID-19 patients in term of overall mortality, initiation of assisted ventilation and duration of hospital stay. ${ }^{11,12}$ With its solid pharma backbone, India has approved domestic manufacturers for the local production of Remdesivir (currently marketed in India by Mylan N. V. as DESREM under emergency authorization). But after the initial results of the WHO Solidarity Trial, ${ }^{11,13}$ there is a need to replan the study.
With no definitive medicine based treatment option, vaccination seems for now as the only hope for the prevention of COVID-19. Currently, more than 50 COVID-19 vaccine candidates are under various phases of clinical trials. ${ }^{14}$ Out of these, two vaccines, namely Tozinameran/ Comirnaty (Pfizer) and mRNA-1273 (ModernaTX) were approved and authorized by the US Food and Drug Administration (FDA) for emergency use in the USA on December 11, 2021, and December 18, 2021, respectively. ${ }^{15,16}$ In addition, some more vaccines such as AZD1222 (the University of Oxford and AstraZeneca), AD5-nCOV/Convidicea (CanSino Biologics), BBIBPCorV (Sinopharm), CoronaVac (Sinovac), Gam-COVIDVac/Sputnik V (Gamaleya Research Institute of Epidemiology and Microbiology), and COVAXIN/ BBV152 (Bharat Biotech) were also developed and authorized by various countries/regulatory bodies for mass vaccination across the globe. ${ }^{17-22}$

\section{COVID- 9 Vaccination Program in India}

With its enormously large population stretched out in urban and rural sectors, India's universal immunization program (UIP) is one of the largest of its type in the world, targeting close to 2.67 crore newborns and 2.9 crore pregnant women annually. ${ }^{23}$ For the present COVID-19 crisis, India requires adequate resourcing and preparing the ground for challenges related to the effective distribution in vaccine delivery, logistics, manufacture, and availability. According to the Government, ten vaccine candidates have been supported by the Department of Biotechnology (DBT), and five are in human trials, including the Russian Vaccine Sputnik-V. The Indian leadership announced a 900 crore (\$121.6 million) financial stimulus package called Mission COVID Suraksha (safety) to accelerate the vaccine development program further. ${ }^{23}$ It is worth mentioning that India's immunization program is essentially tuned to deliver childhood vaccination (except for pregnant women). With no adult vaccination in place, there are enormous challenges to accomplish the mission, specifically to reach out to remotely located populations. ${ }^{23}$

To streamline the COVID-19 vaccine logistics, India developed the Electronic Vaccine Intelligence Network (eVIN), which digitizes the entire vaccine stock management, logistics, and cold chain tracking of all country's vaccine storage levels. eVIN, in association with the United Nations Development Program (UNDP), will 
identify primary beneficiaries and vaccine distribution networks. $^{24,25}$ National Center for Cold Chain Development along with National Cold Chain \& Vaccine Management Resource Centre (NCCVMRC), under the aegis of National Institute of Health and Family Welfare (NIHFW), are categorically established to monitor this process (http://www.nccmis.org). This apex body under the Government provides technical support on its immunization supply chain. So far, with 29,000 cold chains established across the country, the Indian administration is gearing up to combat COVID-19 spread in this country $^{26}$ - India is planning to vaccinate about 300 million people in its first phase.

\section{Impact of COVID-I 9 on Indian Economy and Government Emergency Response}

India's informal sector, one of the highest among the five South Asian countries currently employing $80.9 \%$ of the workforce, seems to be the most vulnerable. ${ }^{27}$ With a service sector-based economy in India, contributing a whopping $\sim 54 \%$ of total gross domestic product (GDP), it took the biggest hit. Over 122 million Indians lost their jobs only in April 2020 due to the COVID-19 countrywide lockdown. Around 75\% (91 million) of them were only daily wage-earning low paid workers. About one hundred million jobs in India will be at risk postCOVID-19 lockdown stage with an estimated 15-30\% layoff in several sectors. ${ }^{28}$ What is even worst is that a significant fraction of these jobs might be gone forever as employers learned that automation and e-commerce platforms are more reliable than humans. With corporated adapting to manage with a scaled-down workforce, "work from home" is a new normal. After all, this serves the dual purpose, reducing infrastructure and overhead cost plus managing with lesser staff. With the economy nose driving and growth rates running into negatives, the Indian economy, which was already sick, now seems to be rushed for ventilator support. Without a government bailout, several private sectors are doomed and heading to file for bankruptcy. Almost $80 \%$ of Indian companies have encountered a severe cash crunch, with over $50 \%$ of companies facing operations issues. The Federation of Indian Chambers of Commerce and Industry (FICCI) stated that the pandemic had impacted close to $60 \%$ of companies affecting repayments, interest, taxes, employment, pensions, etc. ${ }^{29}$
With the service and industrial sector plummeting, and with 140 million farm households across the country, India's agricultural sector currently employs a $41.49 \%$ workforce and is also facing stagflation. ${ }^{30}$ Post COVID19 will encourage a re-designing of this undermined yet indispensable sector of India's economy.

The Government is doing its best to overcome this helpless situation as it is wagging to decide the best strategy to strike a balance to revive the economy without jeopardizing its citizens' health. Without an economic revival, it is imminent that India could be heading towards a global famine and skyrocketed poverty with catastrophic consequences. But jump-starting business, as usual, means exposing the citizens to the virus. This also risks stretching the healthcare system to its ceiling. Choosing either of them will come at a hefty price. There is a crucial tradeoff here. Winning over COVID-19 completely seems a remote possibility; instead, minimizing the fatality and mitigating risk is the prime mantra now. This was recently witnessed in India, in the aftermath of lockdown and closure of work-sites and income, forced more than ten millions of laborers and low wage workers with their families hitting the streets to undertake an exodus journey of several hundred kilometers long by-foot, ${ }^{31,32}$ from the urban agglomerations back to their village home, carrying with them the disease, depression and shattered dreams of climbing the social ladder. Administrations could do little to prevent these peoples from violating state-issued guidelines and restrictions. Social distancing and other preventive measures might become useless once people are on the streets, desperate for jobs, and responsible for feeding families back home. It is a catch 22 situation. Through the union government's initiative, "Self-reliant India Mission" with a special relief package worth Rs.20 trillion, it has helped the country restore the derailed economy to some extent. However, more financial boost is still required to regain the pre-COVID-19 situation in India. ${ }^{33}$

In the health care sector, the role and responsibilities of the Government are several-fold. To combat COVID-19 situation in the country, the Indian Government has sanctioned a package of Rs.15000 crore as an 'India COVID19 Emergency Response and Health System Preparedness Package just after the announcement of 1st phase of countrywide lockdown. ${ }^{34}$ With a population of 1.3 billion, COVID-19 testing for the entire community is nearly an impossible task. The priorities are for the healthcare provider and those who are immunocompromised with existing comorbidities, though, as of January 03, 2021, India 
tested a total of $17,48,99,783$ samples. ${ }^{35}$ The Government has also expanded its testing capacity by engaging a network of 2295 laboratories, including 1094 private laboratories, to speed up the pace of early and timely diagnosis of COVID-19 suspected cases. ${ }^{36}$ The Government has also slashed the prices for COVID-19, RT-PCR testing by one fourth to encourage greater participation and quarantine the positive cases. The Indian Council of Medical Research (ICMR) has enthusiastically supported the development of affordable in-house COVID-19 testing kits, tailored for addressing the disease burden in India, thereby minimizing the need to import. $^{37,38}$ Further, approving academic grants for COVID-19 research, funds for innovation of novel labbased diagnostic kits, drug repurposing, and disease management are enthusiastically supported. ${ }^{39,40}$ The Indian Government's Ministry of Ayurveda, Yoga \& Naturopathy, Unani, Siddha and Homeopathy (AYUSH), a non-allopathy based alternative medicine system, advocates natural and herbal compound-based formulations and lifestyle changes, serving the purpose of natural-therapy and immune modulation. ${ }^{41-43}$

\section{Additional Government Initiative}

To contain the massive spread of COVID-19 in India, the Government has taken appropriate steps like imposing mandatory wearing of face mask and maintaining social distancing in public places, closure of schools, colleges as well as mass transit systems like metro and rail, subsidize the costs for COVID-19 testing and home or institutional quarantine for positive cases. Around 5,321 Railway coaches were improvised and converted into isolation units and quarantine zones at the cost of Rupees 10 million. ${ }^{44}$ Domestically developed, rapid antigen and antibody-based assays are used for quick mass screening. The ICMR also initiated a multicentric clinical trial in convalescent plasma transfusion therapy. ${ }^{45}$ India is also launching this January 16, 2021, its first indigenously developed COVID-19 inactivated vaccine, COVAXIN (BBV152), developed by an Indian Pharmaceutical company, Bharat Biotech, Hyderabad, in collaboration with the ICMR - National Institute of Virology (NIV), Pune. $^{46}$ A second vaccine, ie, Covishield, is also on the way for mass application, developed by the world's largest India-based vaccine manufacturing company Serum Institute of India, as an Indian variant of AZD1222 vaccine developed jointly by Oxford University and AstraZeneca. ${ }^{47}$ In India, these two vaccines were granted approval by the National Regulatory Authority (ie, Central Drugs Standard Control Organization, New Delhi) on January 3, 2021 for restricted use in the country. ${ }^{48}$

While COVID-19 has hurt the backbone of the Indian economy, it also brought novel opportunities for Indians to stand self-reliantly even in a crisis. Before COVID-19, India has zero production of PPE kits, and almost all the demands of PPE kits were met by importing the products from other countries. During the COVID-19 crisis, India has started producing PPE Kits domestically and fulfilling its needs within a brief period. Nowadays, India is one of the largest producers of PPE kits in the world. ${ }^{49,50}$ Moreover, India has also started mass-level production of ventilators to meet its requirement, and Indian firms manufactured more than 50,000 in just a few months. ${ }^{51}$

\section{Possible Solutions and Future Recommendation: Lessons Learned from the Present Crisis}

Though a matter of debate, there is a suggestive twopronged approach to fix both the ailing economy and healthcare crisis since the two are intimately linked. The markets are witnessing double trouble. The productions are still down, and consumption is at the lowest. Inflation is rising steadily, and the GDP is declining. ${ }^{52}$ The Government must provide liquidity to the economically deprived sections in cash transfer to stimulate demand. Further, a limited but focussed approach needs to be undertaken to re-energize the health sector and economy, namely injecting cash and encouraging lending, regulatory deferrals, and providing health insurance for health professionals and food and ration for the poor. This should also be accompanied by waiving off loan repayments and handling large fiscal packages to jump-start the economy to expand government-subsidized schemes.

For the health care sector, the Government should make the COVID-19 testing facility free to all citizens to identify disease carriers and improvise on cheaper, domestically produced, and frugal ways to perform massscreening and testing, cutting the cost per assay. The Government needs to ensure greater participation of private health care providers too in this initiative. There are concerns since, in a survey, $47.4 \%$ of healthcare providers felt that the private medical sector's contribution has been suboptimal. 58.2\% thought that the Government had not 
adequately involved the private sector; $45.1 \%$ thought they should be part of policy-making. ${ }^{53}$

As far as disease diagnostic is concerned, India will further need to expand its nationwide network of viral diagnostic laboratories ${ }^{54}$ to the block/district levels to meet the increasing demand and set up multicentric COVID and related infectious disease specialty hospitals. India is also going to set up a pathogen research center with countrywide branches to identify and track future spillover infections affecting humans. ${ }^{54,} 55 \mathrm{We}$ must accept that all this will work only by collectivism, not by individualism. A peacetime training program in handling potentially contagious diseases need to be undertaken to keep preparedness at the toe so that teams of highly skilled and trained medics can be rushed to the outbreak site to contain the spread and minimize human loss efficiently- Repurposing of generic drugs and the vast array of India's natural compound libraries to screen for therapeutic agents need to be pursued seriously against future infectious agents.

Further, disease hotspots need to be monitored meticulously using real-time surveillance systems without compromising their citizens' privacy. ${ }^{56}$ Under the central government initiative, a mobile-based app called "AAROGYA SETU"57,58 was launched to address this issue precisely.

\section{Conclusion}

COVID-19 has unleashed a disproportionate crisis that has overwhelmed both the economy and India's health care sector. The Government needs to act swiftly on both these fronts to compensate for the loss and minimize future cataclysm. This ensures that adequate risk management protocols are in place, which can generate trust and confidence within the population, a majority of whom are below the poverty line and are heavily dependent on government aid and Government-subsidized programs. The year 2020 has witnessed a massive job loss and shrinking income across all sectors, with the heaviest toll in the informal sector, making the most substantial fraction of the Indian workforce. ${ }^{59,60}$ With a poor infrastructure to provide adequate healthcare, India's trajectory for recovery postCOVID is full of procrastination unless it acts meticulously to address the existing lacunae's adoptive cohesion policy to uplift the social-economic status of its population.

In spite of several downtrends, the markets continue to soar as the demands slowly tend to increase. Transaction through digital payment touched a record high in the year
2020 as an alternative to a contactless transaction. ${ }^{61,62}$ In the healthcare sector, India did a remarkable job in reducing COVID-19 related hospitalization and mortality. One of the most satisfactory achievements so far is the rapid development of two indigenously produced COVID-19 vaccine. This will surely raise the confidence and provide a psychological boost for its citizens. Balancing both economic and public health is undoubtedly challenging but is perhaps the only rational option that a nation of 1.3 billion can adopt to overcome the present crisis.

Finally, to quote noble laureate Esther Duflo, ${ }^{63}$

There is no tradeoff in emerging countries between helping people sustain themselves financially and getting the health conditions to improve; the two have to go hand in hand. Because if you cannot assure people that they will be able to eat in the future, then it is going to be impossible for them to stay home.

\section{Author Contributions}

All authors made a significant contribution to the work reported, whether that is in the conception, study design, execution, acquisition of data, analysis and interpretation, or in all these areas; took part in drafting, revising or critically reviewing the article; gave final approval of the version to be published; have agreed on the journal to which the article has been submitted; and agree to be accountable for all aspects of the work. Corresponding author SK has conceptualized and overseen the entire work.

\section{Funding}

There is no funding to report.

\section{Disclosure}

The authors declare no conflict of interests for this work.

\section{References}

1. Worldometer. COVID-19 Coronavirus Pandemic; 2021. Available at: https://www.worldometers.info/coronavirus/. Accessed January 03, 2021.

2. World Bank. World development indicators. Available from: https:// databank. worldbank.org/reports.aspx? source=2\&series=NY.GDP. MKTP.CD\&country=\#. Accessed January 03, 2021.

3. Shah S, Das S, Jain A, Misra DP, Negi VS. A systematic review of the prophylactic role of chloroquine and hydroxychloroquine in coronavirus disease-19 (COVID-19). Int J Rheum Dis. 2020;23(5):613-619. doi:10.1111/1756-185X.13842

4. Elavarasi A, Prasad M, Seth T, et al. Chloroquine and hydroxychloroquine for the treatment of COVID-19: a systematic review and meta-analysis. J Gen Intern Med. 2020;35(11):3308-3314. doi:10.1007/s11606-020-06146-w 
5. Singh AK, Singh A, Singh R, Misra A. Hydroxychloroquine in patients with COVID-19: a systematic review and meta-analysis. Diabetes Metab Syndr. 2020;14(4):589-596. doi:10.1016/j. dsx.2020.05.017

6. Blamont M, Smout A, Parodi E. EU governments ban malaria drug for COVID-19, trial paused as safety fears grow; 2020. Available from: https://in.reuters.com/article/health-coronavirus-

hydroxychloroquine-fr/eu-governments-ban-malaria-drug-for-covid -19-trial-paused-as-safety-fears-grow-idINKBN2340A6. Accessed February 4, 2021.

7. Boulware DR, Pullen MF, Bangdiwala AS, et al. A randomized trial of hydroxychloroquine as postexposure prophylaxis for covid-19. N Engl J Med. 2020;383(6):517-525. doi:10.1056/NEJMoa2016638

8. Skipper CP, Pastick KA, Engen NW, et al. Hydroxychloroquine in nonhospitalized adults with early COVID-19: a randomized trial. Ann Intern Med. 2020;173(8):623-631. doi:10.7326/M20-4207

9. Beigel JH, Tomashek KM, Dodd LE, et al. Remdesivir for the treatment of covid-19 - final report. $N$ Engl J Med. 2020;383 (19):1813-1826. doi:10.1056/NEJMoa2007764

10. Kalil AC, Patterson TF, Mehta AK, et al. Baricitinib plus remdesivir for hospitalized adults with covid-19. $N$ Engl J Med. 2020: NEJMoa2031994. doi:10.1056/NEJMoa2031994

11. Pan H, Peto R, Karim QA, WHO Solidarity Trial Consortium. Repurposed antiviral drugs for covid-19 - interim WHO solidarity trial results. $N$ Engl J Med. 2020:NEJMoa2023184. doi:10.1056/ NEJMoa2023184

12. Indian Council of Medical Research. Press release. Solidarity trial, coordinated by WHO and executed by ICMR in India, answers critical questions about COVID-19 therapeutics. October 16, 2020. Available from: https://www.icmr.gov.in/pdf/press_realease_files/ ICMR_Press_Release_Solidarity_16102020_v1.pdf. Accessed January 03, 2021.

13. Siemieniuk R, Rochwerg B, Agoritsas T, et al. A living WHO guideline on drugs for covid-19. BMJ. 2020;370:m3379. doi:10.1136/bmj.m3379

14. World Health Organization. COVID-19 vaccines. Available from: https://www.who.int/emergencies/diseases/novel-coronavirus-2019/ covid-19-vaccines. Accessed January 03, 2021.

15. US Food \& Drug Administration. Pfizer-BioNTech COVID-19 Vaccine; 2021.Available from: https://www.fda.gov/emergencypreparedness-and-response/coronavirus-disease-2019-covid-19/pfi zer-biontech-covid-19-vaccine. Accessed January 03, 2021.

16. US Food \& Drug Administration. Moderna COVID-19 Vaccine; 2021.Available from: https://www.fda.gov/emergency-preparednessand-response/coronavirus-disease-2019-covid-19/moderna-covid-19vaccine\#translations. Accessed January 03, 2021.

17. Center for Disease Control. Different COVID-19 Vaccines. Available from: https://www.cdc.gov/coronavirus/2019-ncov/vaccines/differ ent-vaccines.html. Accessed January 03, 2021.

18. Pandey SC, Pande V, Sati D, Upreti S, Samant M. Vaccination strategies to combat novel corona virus SARS-CoV-2. Life Sci. 2020;256:117956. doi:10.1016/j.lfs.2020.117956

19. Tregoning JS, Brown ES, Cheeseman HM, et al. Vaccines for COVID-19. Clin Exp Immunol. 2020;202(2):162-192. doi:10.1111/ cei. 13517

20. Heaton PM. The covid-19 vaccine-development multiverse. $N$ Engl $J$ Med. 2020;383(20):1986-1988. doi:10.1056/NEJMe2025111

21. Koirala A, Joo YJ, Khatami A, Chiu C, Britton PN. Vaccines for COVID-19: the current state of play. Paediatr Respir Rev. 2020;35:43-49. doi:10.1016/j.prrv.2020.06.010

22. Ministry of Health and Family Welfare, Government of India. National Health Mission. Available from: https://nhm.gov.in/index1.php?lang= 1\&level=2\&sublinkid=824\&lid=220. Accessed February 4, 2021.

23. Adil A. India faces 'challenges' in nationwide virus vaccination. Anadolu Agency. 2020 Dec 5. Available from: https:// www.aa.com.tr/en/asia-pacific/india-faces-challenges-in-nationwidevirus-vaccination/2066377. Accessed February 4, 2021.
24. Bhatia V. Explained: What is eVIN, and how will it be used for distributing Covid-19 vaccines? The Indian Express. 2020 Dec 1. Available from: https://indianexpress.com/article/explained/what-isevin-and-how-will-it-be-used-for-distributing-covid-19-vaccine -7065083/. Accessed February 4, 2021.

25. United Nations Development Programme. Improving the efficiency of vaccinations systems in multiple states. Available from: https:// www.in.undp.org/content/india/en/home/projects/gavil.html. Accessed February 4, 2021

26. New Delhi Bureau. With 29,000 cold chains, India readying for Covid vaccination: Health Secretary. The Hindu: Business Line. 2020 Dec 15. Available from :https://www.thehindubusinessline. com/news/with-29000-cold-chains-india-readying-for-covidvaccination-health-secretary/article33339606.ece. Accessed February 4, 2021.

27. Wikipedia. COVID-19 vaccine. Available from: https://en.wikipedia. org/wiki/COVID-19_vaccine. Accessed January 03, 2021.

28. Centre for Monitoring Indian Economy Pvt. Ltd. Homepage. Available from: https://www.cmie.com/. Accessed February 4, 2021.

29. Misra R. Coronavirus (COVID-19) : Impact on Indian Business and Economy. Paisabazaar. 2021 Feb 1. Available from: https://www.paisa bazaar.com/business-loan/coronavirus-impact-on-indian-business-andeconomy. Accessed February 4, 2021.

30. International Labour Organization. Women and Men in the Informal Economy: A Statistical Picture. 3rd Ed. Geneva: ILO; 2018. Available from: https://www.ilo.org/wcmsp5/groups/public/—dgre ports/—dcomm/documents/publication/wcms_626831.pdf.

31. World Bank. Employment in agriculture (\% of total employment) (modeled ILO estimate) - india. Available from: https://data.world bank.org/indicator/SL.AGR.EMPL.ZS?locations $=$ IN. Accessed January 03, 2021.

32. Over one crore migrant laborers returned to home states on foot during Mar-Jun: govt. Available from: https://indianexpress.com/arti cle/india/over-1-crore-migrant-labourers-returned-to-home-states-onfoot-during-mar-jun-govt-6606347/. Accessed January 03, 2021.

33. Government of India. Building Atmanirbhar Bharat and overcoming COVID-19. Available from: https://www.india.gov.in/spotlight/build ing-atmanirbhar-bharat-overcoming-covid-19.

34. Government of India. New Delhi: Ministry of Health and Family Welfare. Government of India sanctions Rs. 15000 crores for India COVID-19 Emergency Response and Health System Preparedness Package; 2020. Available from: https://pib.gov.in/ PressReleaseIframePage.aspx?PRID $=1612534$. Accessed January 03, 2021.

35. Indian Council of Medical Research. Homepage. Available from: https://www.icmr.gov.in/. Accessed January 03, 2021.

36. Indian Council of Medical Research. Information for Testing Laboratories (Archive); Total Operational Laboratories. Available from: https://www.icmr.gov.in/arcctestlab.html. Accessed January 03, 2021.

37. Indian Council of Medical Research. Information For Testing Laboratories; 2020. Available from: https://www.icmr.gov.in/ctes tlab.html. Accessed February 4, 2021.

38. Indian Council of Medical Research. Kits Validation \& Batch Testing. Available from: https://www.icmr.gov.in/ckitevaluation. html. Accessed February 4, 2021.

39. Sharma U. ICMR accepts proposal for fast track funding opportunities for COVID-19 translational immunology research. Express Healthcare. 2020 Apr 22. Available from: https://www.expresshealth care.in/covid19-updates/icmr-accepts-proposal-for-fast-track-funding -opportunities-for-covid-19-translational-immunology-research /419115/. Accessed February 4, 2021.

40. ETCFO. COVID-19 Hotspots: ICMR grants approval for antibody testing. The Economic Times. 2020 Apr 3. Available from: https://cfo. economictimes.indiatimes.com/news/covid-19-hotspots-icmr-grantsapproval-for-antibody-testing/74967578. Accessed February 4, 2021. 
41. Golechha M. Time to realize the true potential of Ayurveda against COVID-19. Brain Behav Immun. 2020;87:130-131. doi:10.1016/j. bbi.2020.05.003

42. Tillu G, Chaturvedi S, Chopra A, Patwardhan B. Public health approach of ayurveda and yoga for COVID-19 prophylaxis. J Altern Complement Med. 2020;26(5):360-364. doi:10.1089/acm.2020.0129

43. Gupta H, Gupta M, Bhargava S. Potential use of turmeric in COVID-19. Clin Exp Dermatol. 2020;45(7):902-903. doi:10.1111/ced.14357

44. Dastidar AG. Explained: How railway coaches were redesigned for COVID-19 patients, where they will be deployed. The Indian Express. 2020 Jun 19. Available from: https://indianexpress.com/arti cle/explained/railway-station-covid-isolation-coaches-coronaviruspatients-anand-vihar-delhi-6462371/. Accessed January 03, 2021.

45. Indian Council of Medical Research. Technical Documents \& Advisory. Available from: https://www.icmr.gov.in/ctechdocad.html. Accessed February 4, 2021.

46. Bharat Biotech. COVAXIN ${ }^{\mathrm{TM}}$ - India's First Indigenous COVID-19 Vaccine. Available from: https://www.bharatbiotech.com/covaxin. html. Accessed February 4, 2021.

47. Serum Institute of India Pvt. Ltd. COVISHIELD Completes Enrolment of Phase III clinical trials under partnership of ICMR and Serum Institute of India; 2020. Available from: https://www. seruminstitute.com/news sii icmr partnership.php. Accessed February 4, 2021.

48. Kaunain Sheriff M. Explained: Two Covid-19 vaccines approved, what happens now? The Indian Express. 2020 Jan 3. Available from: https:// indianexpress.com/article/explained/explained-oxford-sii-vaccinesapproved-bharat-biotech-covid-19-7130887/. Accessed January 03, 2021.

49. Ethiraj G. COVID-19: How India Became A PPE Kit Manufacturing Hub. Boom. 2020 Jun 8. Available from: https://www.boomlive.in/ videos/boom-money/covid-19-how-india-became-a-ppe-kitmanufacturing-hub-8408. Accessed January 04, 2021.

50. Kapoor A, Goyal S. India's successful journey to self-sufficiency in PPE kits. The Economic Times. 2020 Oct 14. Available from: https:// economictimes.indiatimes.com/industry/healthcare/biotech/health care/indias-successful-journey-to-self-sufficiency-in-ppe-kits/article show/78658109.cms?from=mdr. Accessed January 04, 2021.

51. ANI. Govt COVID hospitals to receive 50,000 'Made in India' ventilators through PM-CARES Fund. The Economic Times: Healthworld. com. 2020 Jun 23. Available from: https://health.economictimes.india times.com/news/hospitals/govt-covid-hospitals-to-receive-50000made-in-india-ventilators-through-pm-cares-fund/76527137. Accessed January 03, 2021.

52. National Statistical Office. Press Note on First Advance Estimates of National Income 2020-21. New Delhi: Ministry of Statistics and Programme Implementation, Government of India; 2021. Available from: https://www.mospi.gov.in/documents/213904/416359//Presss\% 20note_FAE-2020-211610021181596.pdf/9fff7a5d-29da-9a4b-971fcfb7b0f05500. Accessed January 14, 2021.

53. Davalbhakta S, Sharma S, Gupta S, et al. Private health sector in India-ready and willing, yet underutilized in the covid-19 pandemic: a cross-sectional study. Front Public Health. 2020;8:571419. doi:10.3389/fpubh.2020.571419

Risk Management and Healthcare Policy
54. Department of Health Research, India. Establishment of a network of Laboratories for managing epidemics and Natural Calamities (VRDL). Available from: https://dhr.gov.in/schemes/establishmentnetwork-laboratories-managing-epidemics-and-natural-calamities. Accessed January 03, 2021.

55. Sharma NC. ICMR to fight pandemics in future with covid database. Mint. 2020 May 25. Available from: https://www.livemint.com/ science/health/icmr-to-fight-pandemics-in-future-with-covid-data base-11590427664094.html. Accessed February 4, 2021.

56. World Health Organization. Joint Statement on Data Protection and Privacy in the COVID-19 Response. Geneva: WHO. 2020 Nov 19. Available from: https://www.who.int/news/item/19-11-2020-jointstatement-on-data-protection-and-privacy-in-the-covid-19-response. Accessed February 4, 2021.

57. Government of India. Aarogya Setu [phone application]. Available from: https://aarogyasetu.gov.in/. Accessed February 4, 2021.

58. Clarance A. Aarogya Setu: Why India's Covid-19 contact tracing app is controversial. BBC News. 2020 May 14. Available from: https:// www.bbc.com/news/world-asia-india-52659520. Accessed February 4, 2021.

59. Sangeetha G. Even as economic recovery continues, India lost 5.5 lakh jobs in October. Deccan Chronicle. 2020 Nov 6. Available from: https://www.deccanchronicle.com/business/economy/061120/even-as -economic-recovery-continues-india-lost-55-lakh-jobs-in-octob.html. Accessed February 4, 2021.

60. Business Standard Desk. GDP contraction to job losses amid Covid19: 2020, the year of new lows. Business Standard. 2020 Dec 27. Available from: https://www.business-standard.com/article/econ omy-policy/gdp-contraction-to-job-losses-amid-covid-19-2020-theyear-of-new-lows-120122700761_1.html. Accessed February 4, 2021.

61. Surabhi. Fintech: Digital payments got a Covid boost in 2020. The Hindu: Business Line. 2020 Dec 25. Available from: https://www. thehindubusinessline.com/money-and-banking/digital-payments-got -a-covid-boost-in-2020/article33419349.ece. Accessed February 4, 2021.

62. ET Government.com: Digital payments swell as $42 \%$ Indians make multiple online payments during Covid-19 lockdown. ETGovernment.com. 2020 Apr 16. Available from: https://govern ment.economictimes.indiatimes.com/news/digital-payments/digitalpayments-swell-as-42-indians-make-multiple-online-paymentsduring-covid-19-lockdown/75172943. Accessed February 4, 2021.

63. Brancaccio D, Conlon R. How to help the poor amid COVID-19? Give them money, says Nobel laureate Esther Duflo. Marketplace. 2020 Apr 9. Available from: https://www.marketplace.org/2020/04/ 09/covid-19-low-income-help-cash-transfers-esther-duflo/. Accessed February 4, 2021.

\section{Publish your work in this journal}

Risk Management and Healthcare Policy is an international, peerreviewed, open access journal focusing on all aspects of public health, policy, and preventative measures to promote good health and improve morbidity and mortality in the population. The journal welcomes submitted papers covering original research, basic science, clinical \& epidemiological studies, reviews and evaluations,

guidelines, expert opinion and commentary, case reports and extended reports. The manuscript management system is completely online and includes a very quick and fair peer-review system, which is all easy to use. Visit http://www.dovepress.com/testimonials.php to read real quotes from published authors. 